\title{
The Role of Flow in the Everglades Landscape ${ }^{1}$
}

H. Fling, N. Aumen, T. Armentano, F. Mazzotti ${ }^{2}$

\section{Introduction}

The Comprehensive Everglades Restoration Plan (CERP) aims to improve water quantity, timing, distribution, and quality of the Greater Everglades System (Figure 1) over the next 35 years (SFERTF 1998). Not only is it the most expensive ( 8 billion dollars, 1999) and ambitious ecological restoration ever undertaken, but it involves multiple agencies and organizations analyzing natural and ecological attributes to recover the natural system. A critically important but often overlooked aspect of the Everglades is the role of flow--the actual movement of water across the landscape--in creation and maintenance of habitats for Everglades plants and animals. Successful restoration of the Everglades landscape requires a thorough understanding of the role of flow (SCT 2003).

\section{Ridge and Slough Landscape}

\section{Pre-drainage Everglades}

Two of the main ecosystems formed in the Everglades marsh system were the sawgrass plains in the north and the ridge and slough landscape in the center and south (Figure 1). Extensive communities

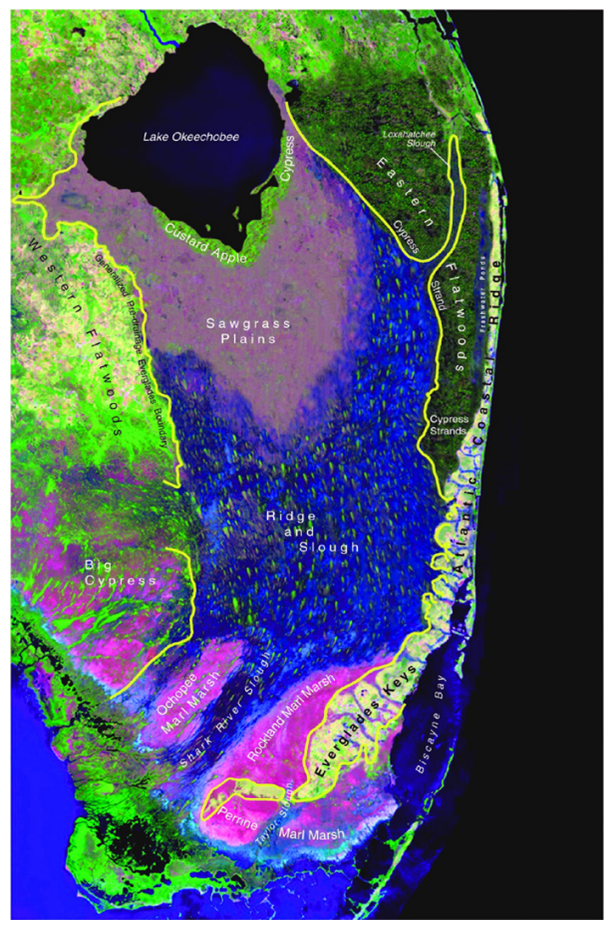

Figure 1. Ridge and slough landscape within the predicted pre-drainage system, circa 1850. Credits:

http://sofia.usgs.gov/sfrsf/rooms/hydrology/water/ wherebefore.html

of freshwater wetland vegetation including somewhat regularly distributed tree islands made the ridge and slough landscape, resemble a patterned peatland. The

1. This document is CIR1452, one of a series of the Wildlife Ecology and Conservation Department, University of Florida Cooperative Extension Service, Institute of Food and Agricultural Sciences. Publication date: December, 2004. Visit the EDIS Web site at http://edis.ifas.ufl.edu.

2. Holly E. Fling, Graduate Student at Duke University's Nicholas School of the Environment and Earth Sciences, Durham, NC. Nicholas G. Aumen, Aquatic Ecologist, Everglades National Park, c/o Arthur R. Marshall Loxahatchee National Wildlife Refuge, Boynton Beach, Florida; Dr. Tom Armentano, Ecological Consultant, Florida. Frank J. Mazzotti, Ph.D., Associate Professor, Department of Wildlife Ecology and Conservation, University of Florida, Fort Lauderdale Research and Education Center, Fort Lauderdale, Florida.

The Institute of Food and Agricultural Sciences (IFAS) is an Equal Opportunity Institution authorized to provide research, educational information and other services only to individuals and institutions that function with non-discrimination with respect to race, creed, color, religion, age, disability, sex, sexual orientation, marital status, national origin, political opinions or affiliations. U.S. Department of Agriculture, Cooperative Extension Service, University of Florida, IFAS, Florida A. \& M. University Cooperative Extension Program, and Boards of County Commissioners Cooperating. Larry Arrington, Dean 
slight elevation gradient from Lake Okeechobee to Florida Bay (less than $4.5 \mathrm{~cm}$ per $\mathrm{km}$ ) made a $48 \mathrm{~km}$-wide sheet of water flowing over and channeling through the peat. Ridges were alternately spaced and a lack of drainage channels implies that water spread out over the entire $48 \mathrm{~km}$ breadth. Early measurements reveal that the water averaged $15 \mathrm{~cm}-1 \mathrm{~m}$ deep and was rarely stagnant traveling $34 \mathrm{~m}$ per day (NPS 1997). The sheet flow's spatial extent was vast and dominated the pre-drainage Everglades hydrology. This pattern of water flow is thought to have formed and maintained the ridge and slough landscape (Kushlan 1993). "The water is pure and limpid and almost imperceptibly moves, not in partial currents, but, as it seems, in a mass, silently and slowly..." (Smith 1848 in Trustees 1881). Though the historical documentation of the ridge and slough landscape is limited, there is a strong similarity between the original direction of flow, alignment of ridge and sloughs, and tree-island orientation (SCT 1997).

Peat heights between ridges and sloughs differed by about $0.5-1 \mathrm{~m}$, resulting in an ecosystem filled with water throughout the year, with areas flooded or dry depending on the season. A cross sectional diagram (Figure 2) is drawn to scale to demonstrate the landscape. Although debate remains, as indicated in the Natural Systems Model (Fennema et al. 1994, VanZee 1999), historical records suggest that sloughs were covered by water approximately nine months of the year, and some tree islands were flooded for perhaps three months each year (McVoy et al. in review). The interaction of habitat heterogeneity with dynamic water storage and sheet flow made a unique and diverse habitat for native flora and fauna.

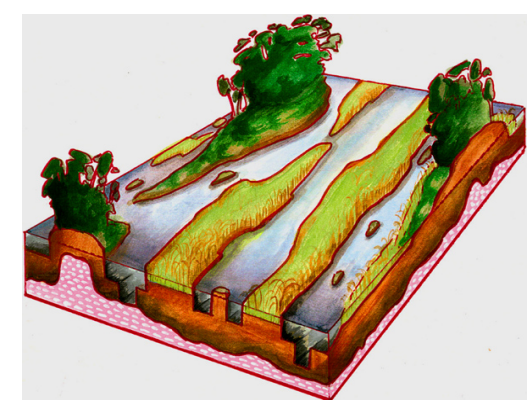

Figure 2. Artists rendering of ridge and slough landscape. Ridges and sloughs drawn to scale relative to each other. Credits: Chris McVoy, SCT 2003

\section{Development in South Florida}

With the beginning of human habitation in the mid-1800s, about $200 \mathrm{~km}^{2}$ north and west of Lake Okeechobee were ditched and drained for agriculture (Trustees 1881). Development continued, and with the floods of 1947-1948, the federal government authorized the Central and Southern Florida Flood Control Project. Massive public works construction projects created the East Coast Protective Levee destroying about $2,500 \mathrm{~km}^{2}$ of the Everglades ecosystem (Lord 1993). A levee was also built to buffer Lake Okeechobee degrading around $11,650 \mathrm{~km}^{2}$ of Everglades watershed (Lord 1993). With development and the creation of Water Conservation Areas 1, 2, 3 and the Everglades Agricultural Area (EAA), just over $15,000 \mathrm{~km}^{2}$ of marsh and watershed have been lost (Lord 1993). Although some hinted at the importance of the Everglades system and the need for its preservation in the 1920s, the economic push for development proved too strong. Marjorie Stoneman Douglas's book, The Everglades: River of Grass (1947) could do nothing to stop drainage and flood control for urbanization, agriculture, and development.

Construction begun in earnest in the early 1900s blocked water flow and began to impact the ridge and slough landscape. In 1910, debate ensued over construction of the Tamiami Trail, with Tatum (Tamiami Trail Commissioners 1928) warning that the road would serve as a dam for southward flowing water. Documentation exists of water flowing over the trail in years of flooding. Aerial photographs just 12 years after completion revealed the drastic difference in landscapes that may have been caused by the barrier to flow. Levee and dam construction continued throughout the 1900s and further fragmented and compartmentalized the ridge and slough landscape as exemplified with Alligator Alley (I-75). The effect of channeling the landscape is demonstrated in Figure 3. 


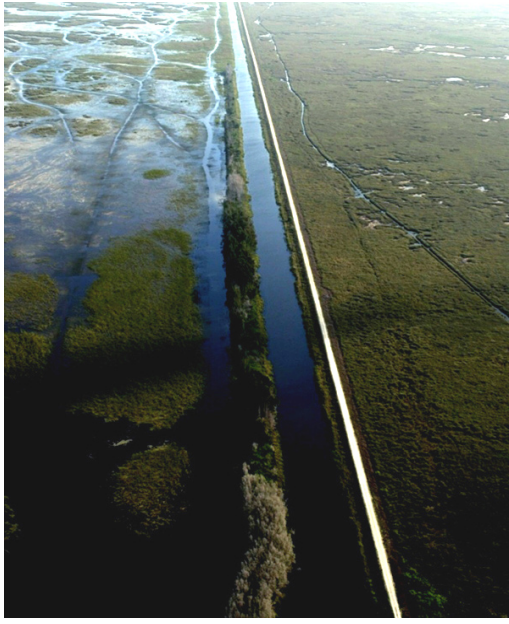

Figure 3. Ridge and slough landscape severely degraded where water flow is disrupted. Credits: Chris McVoy, SFWMD

\section{A Changing Ridge and Slough Landscape}

Loss of ridge and slough landscape is defined by the Science Coordination Team (2003) as a loss of elevation difference between ridge height and slough depths resulting in a flattening of the landscape and a loss of distinct ridge and slough vegetation growth aligning with flow direction. Early predrainage documentation and photographs reveal an organized pattern of congruent landscape, vegetation, and flow similar to Figure 4, while post-drainage documentation reveals a scattered, blurred, and unstructured landscape similar to Figure 5.

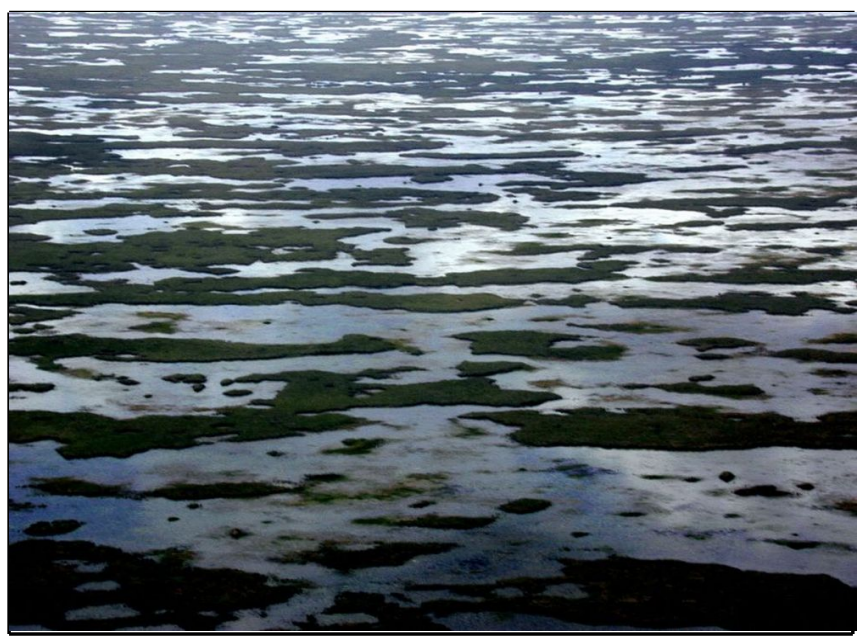

Figure 4. Well-preserved ridge and slough habitat from Water Conservation Area 3A. North is to the left, dark strips are sawgrass ridges, light areas are open water sloughs. Credits: Chris McVoy, aerial photo June 2001.
It is undeniable that the ridge and slough landscape is disappearing and though causes of these changes are not known definitively, initial evidence points to direction, speed, and rate of flow as having large effects on parallel ridges, sloughs, and tree islands (NRC 2003). Greatest ridge and slough degradations are in areas like WCA2 and 3B where water flow has been affected the most (Armentano pers. comm.). The SCT (2003) argues that ridge and slough degradation likely results from changes in water depth and seasonal variations along with flow redirection as a result of constructed barriers (NRC 2003). Though mechanisms of creation and maintenance of ridge and slough landscapes have not yet been documented, it is imperative that the remaining ridge and sloughs be preserved. Current scientific understanding supports flow as a fundamental component of ridge and slough restoration.

There also is strong evidence that loss of the ridge and slough landscape is having a negative effect on Everglades plants and animals. Loss of landscape diversity results in loss of habitat, foraging areas, and refugia for wading birds, fish, and other animals (SCT 2003). Wading bird nesting numbers have decreased by $75-90 \%$ of original population (Ogden 1994) and alligator holes are now absent where they were once prevalent (Craighead 1968, Mazzotti and Brandt 1994). Barriers to flow also represent barriers to migration of animals and barriers to gene flow between adjacent regions of the Everglades (SCT 2003). And drier and more even landscapes also result in altered fire regimes; longer dry seasons resulting in more intense fires (Gunderson and Snyder 1994).

\section{Loss of Water Flow}

Loss of water flow is largely attributed to water management and development and has severely altered the ridge and slough landscape. Elongated ridges aligning with the direction of water flow are evident in Figure 4, which is consistent with pre-drainage patterns, while Figure $5 \& 7$ depict a degraded pattern with amorphous vegetation clusters having no directional alignment. Although some construction attempted to retain the integrity of the flow pattern using canals along the road connecting 


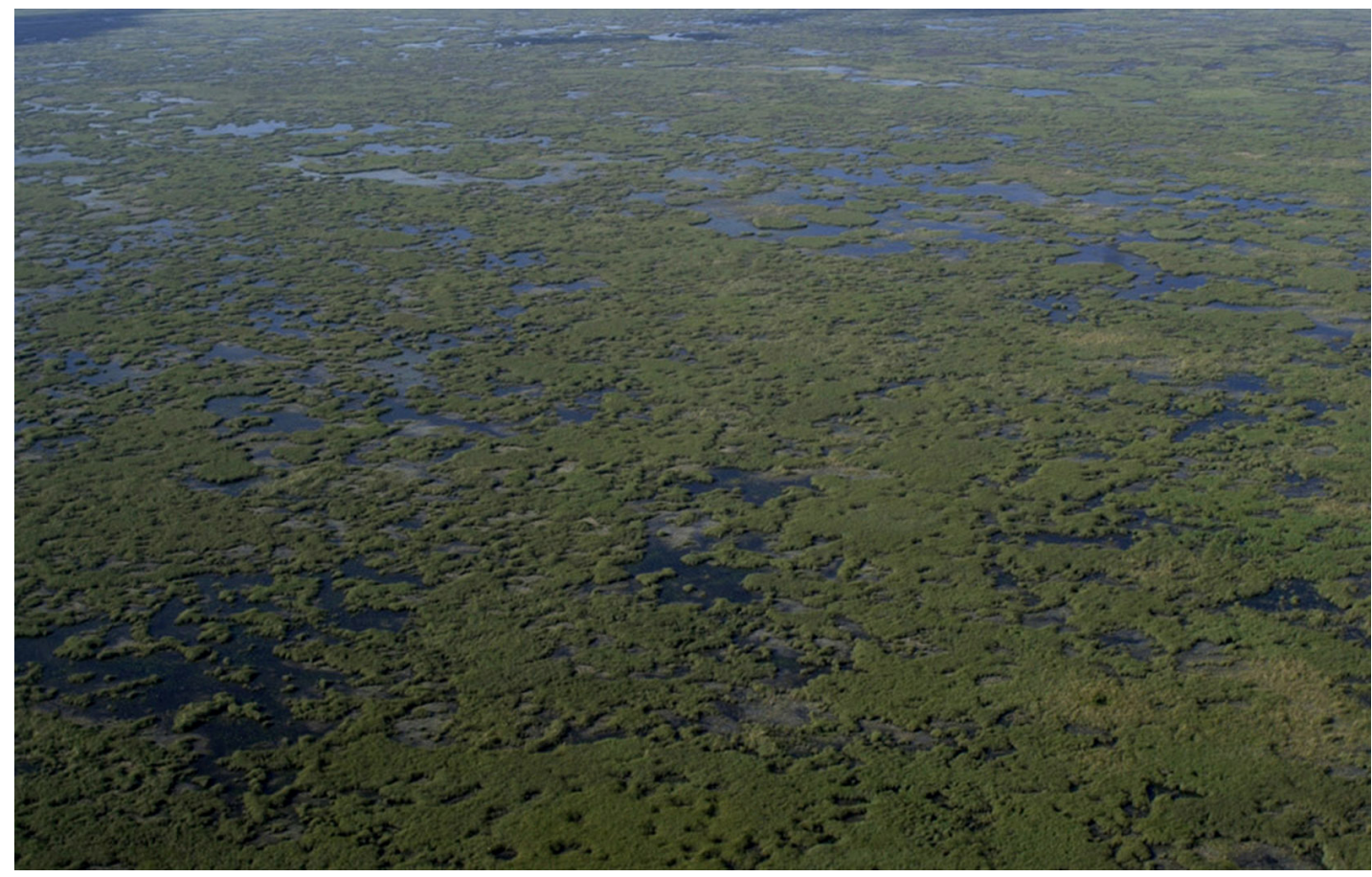

Figure 5. Current degraded ridge and slough landscape in Water Conservation Area 3A, north of Alligator Alley (I-75). Credits: Chris McVoy, aerial photo June 2001.

the ridge and slough landscape every $4 \mathrm{~km}$, the landscape has been greatly degraded. Culverts were put into Alligator Alley (I-75) to try to maintain some water flow. Redirection of water flow severely impacted the ridge and slough landscape upstream and downstream of the Alley (Figure $5 \& 6$ ).

\section{Causes of Ridge and Slough Degradation}

\section{Interruption of Water Flow}

There are several hypotheses as to why the ridge and slough landscape is disappearing. With dams and levees interrupting water flow, it is possible that loss of flow results in loss of sediment transport, resulting in organic material accumulation and filling in of open water habitat (Figure 7). A larger sediment surface area exposed for vegetation growth also could be created by lowering water levels. Lower water levels would result in an increase in vegetation, resulting in increased nutrient uptake and storage.

\section{Loss of Peat Soils}

A flattening of the landscape can also occur with the loss of peat soils from ridges. The shortened

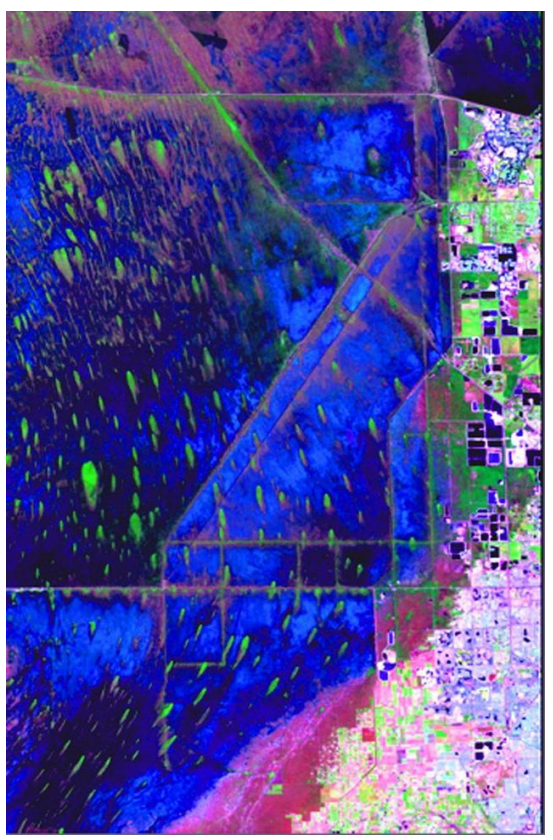

Figure 6. Detailed image of ridge and slough area. Green tear drops are tree islands, altered beneath Tamiami Trail due to flow redirection. Credits: Florida Satellite Image, section 22, SFWMD

http://www.evergladesvillage.net/sat/everglades/

hydroperiod and lowered ground water levels have resulted in areas losing $1 \mathrm{~cm}-1 \mathrm{~m}$ of peat soil (Stober et al. 1996, Sklar et al. 2000). Overdrained ridge and sloughs has lead to the oxidation of top peat layers 


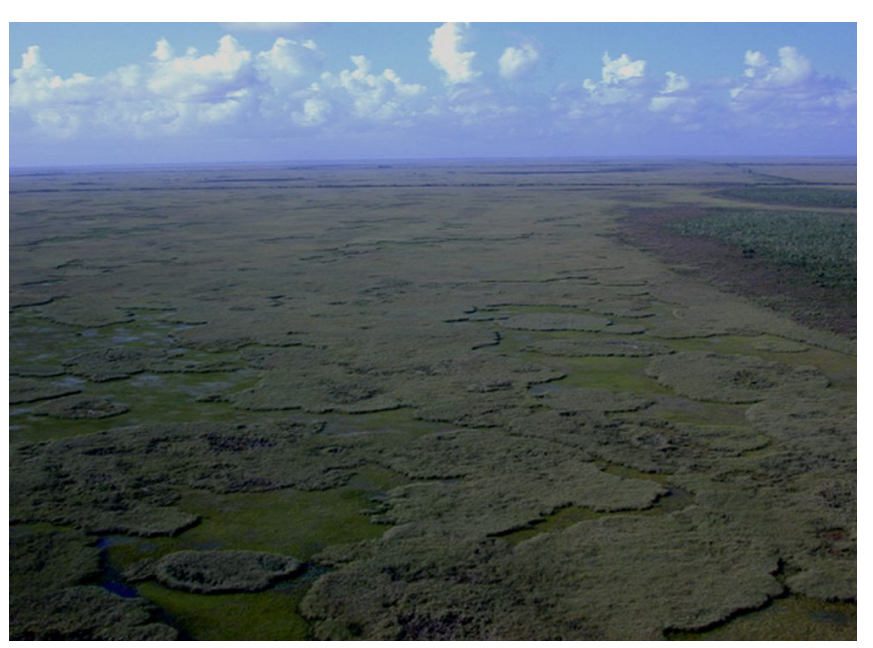

Figure 7. Severely degraded ridge and slough landscape. Unknown location. Credits: Chris McVoy

and more frequent and intense fires. This change in the landscape continues to alter water flow.

\section{Altered Water Level and Quality}

Changes in water levels and water quality also can have adverse effects on ridge and slough landscape. Each vegetation species has optimum ranges of water depths and quality. Therefore when water levels are lower and hydroperiods are shortened, vegetation composition and growth changes. Flow was considered responsible for the vegetation communities of sawgrass (Cladium jamaicense Crantz) growing on ridges and water lilies, spikerush (Eleocharis sp), and beakrush (Rhynchospora sp.) in sloughs and prairies (Sklar et al. 2000). However, altering water level has resulted in sawgrass invasion into sloughs and beakrush dying off. Reduced water quality has resulted in an increase in cattails given their tolerance range. The vegetation species composition has been completely altered (Kolopinski and Higer 1969, Davis and Ogden 1994, Sklar et al. 2000). Natural patterns of succession occur in response to natural variation in hydrology and water quality; however present hydropatterns are altered and eutrophication has exacerbated the problems resulting in unnatural patterns of succession.

\section{Altered Vegetation Decay}

Changes in topography also may be attributed to different rates of vegetation decay. Research has shown that plants that grow in sloughs, such as
Nymphaea odorata, decay much faster than plants that grow on ridges, such as Cladium jamaicense (Davis 1991, Shili Miao, pers. comm.). When comparing field litter, $60 \%$ of sawgrass remained after a year (Davis 1991), while slough species decayed within a few months (Shili Miao, SCT, pers. comm.). The rate of decomposition in sloughs is so great under normal flow conditions that less organic matter accumulates in wet areas like sloughs than on ridges (Heal et al. 1978, Rochefort et al. 1990, van Dierendonck 1992, Johnson and Damman 1991). These decay rate differences could help maintain elevational differences between ridges and sloughs. More stagnant conditions resulting from decreases in flow could decrease dissolved oxygen concentrations in sloughs, slowing down decomposition rates and resulting in faster peat accumulation and eventual filling in of sloughs.

\section{Ongoing Research}

Research continues on processes of ridge and slough creation and maintenance, and effects of water flow and its alteration on the greater Everglades system. Florida International University (FIU) scientists are relating flow to particle production, fate, transport, and deposition (Mitchell-Bruker et al. 2002) and are preparing a model focusing on simulating ridge and slough development and health under varying water management scenarios. This model will be extremely useful in dealing with restoration alternatives. FIU is also determining the hydrological requirements of several major aquatic slough species to evaluate present ridge and slough habitat. Development and survival will be tested at different locations in Shark Slough. The University of Florida is studying soil and water chemistry in relation to how ridge and slough patterns are established and maintained in Shark River Slough. The South Florida Water Management District (SFWMD) is tracking historic patterns in ridge and slough patterns with aerial photography from 1940 to 2003 and relating vegetation growth and decay to flow.

SFWMD scientists seek to understand differing landscape features and how they are maintained and formed through differing vegetation growth, establishment, and habitat requirements. Vegetation 
decay is being compared among sloughs and ridges. The Loxahatchee Impoundment Landscape Assessment (LILA) is a landscape-scale project monitoring biological performance measures and their relation with hydrology to assist with CERP. Within the Everglades landscape, four impoundments have been constructed in which water depth and flow can be altered to induce responses from wildlife, tree islands, and ridge and slough communities. The project is a pilot study for hydrological scenarios under CERP to bring macrocosm effects to larger landscape restorations. LILA is likely to be highly effective because all critical responses (like hydrology) are controlled to replicate historical flow and water patterns. LILA also produces multi-disciplinary results in one study rather than many individual studies and will likely produce strong theories as to the role of flow.

\section{Literature Cited}

Craighead, F.C., Sr. 1968. The role of the alligator in shaping plant communities and maintaining wildlife in the southern Everglades. Florida Naturalist 41:2-7, 69-74, 94.

Davis, S.M. 1991. Growth, decomposition, and nutrient retention of Cladium jamaicense Crantz and Typha domingensis Pers. Florida Everglades. Aquatic Botany 40:203-224.

Davis, S.M. and J. Ogden. 1994. Introduction. Pages 3-7. Davis, S.M. and J.C. Ogden (eds.) Everglades, the Ecosystem and its Restoration. St. Lucie Press, Delray Beach, FL.

Douglas, M.S. 1947. The Everglades River of Grass (revised edition, 1988). Pineapple Press, Sarasota, Florida.

Fennema, R.J., C.J. Neidrauer, R.A. Johnson, T.K. MacVicar, and W.A. Perkins. 1994. A computer model to simulate natural Everglades hydrology. Pages 249-289. Davis, S.M., and J.C. Ogden (eds.) Everglades, the Ecosystem and its Restoration. St. Lucie Press, Delray Beach, FL, USA.

Gunderson, L. H., and J. R. Snyder. 1994. Fire patterns in the southern Everglades. Pages 291-306. Davis, S.M. and J.C. Ogden (eds.) Everglades, the
Ecosystem and its Restoration. St. Lucie Press, Delray Beach, FL.

Heal, O.V., P.M. Latter, and G. Howson. 1978. A study of the rates of decomposition of organic matter. Chapter 7. Pages 136-159. O.W. Heal, and D.F. Perkins (eds.). Production Ecology of British Moors and Montane Grasslands. Ecological Studies 27. Springer-Verlag, New York, New York.

Johnson, L.C., and A.W.H. Damman. 1991. Species-controlled Sphagnum decay on a South Swedish raised bog. Oikos 61:234-242.

Kolopinski, M.C., and A.L. Higer. 1969. Some Aspects of the Effects of the Quantity and Quality of Water on Biological Communities in the Everglades National Park. Open File Report 69007, United States Geological Survey, Washington, D.C., USA.

Kushlan, J.A. 1993. Freshwater wetlands. Pages 74-127. M.S. Dennison and J.F. Berry. Wetlands: Guide to Science, Law, and Technology. Noyes Publications, Park Ridge, New Jersey.

Lord, 1. A. 1993. Guide to Florida Environmental Issues and Information. Winter Park, FL: Florida Conservation Foundation.

Mazzotti, F.J., and L.A. Brandt. 1994. Ecology of the American Alligator in a seasonally fluctuating environment. Pages 485-505. Davis, S.M., and J.C. Ogden (eds.) Everglades, the Ecosystem and its Restoration. St. Lucie Press, Delray Beach, FL, USA.

McVoy, C.W., W.P. Said, J. Obeysekera, and J. VanArman. In review. Pre-drainage landscapes and hydrology of the Everglades.

Mitchell-Bruker, S., D. Childers, M. Ross, L. Leonard, H. Solo-Gabriel, S. Stothoff. 2002. Determining the Role of Sediment Deposition and Transport in the Formation and Maintenance of Tree Islands in the Florida Everglades. American Geophysical Union Spring Meeting 2002.

National Park Service. 1997. Everglades 101: An Introduction to the Ecosystem. Ed. Public Affairs Office. Updated September 9, 1997. www.nps.gov/ever/eco/ever101.htm 
National Research Council (NRC). 2003. Does

Water Flow Influence Everglades Landscape Patterns? National Academies Press. Washington, DC.

Ogden, J.C. 1994. A comparison of wading bird nesting colony dynamics (1931-1946 and 1974-1989) as an indication of ecosystem conditions in the southern Everglades. Pages 533-570. Davis, S.M., and J.C. Ogden (eds.) Everglades, the Ecosystem and its Restoration. St. Lucie Press, Delray Beach, FL, USA.

Rochefort, L., D.H. Vitt, and S.E. Bayley. 1990. Growth, production, and decomposition dynamics of Sphagnum under natural and experimentally acidified conditions. Ecology 71(5):1986-2000.

Science Coordination Team (SCT). 1997. South Florida Ecosystem Restoration Task Force. www.sfrestore.org.

Science Coordination Team (SCT). 2003. The Role of Flow in the Everglades Ridge and Slough Landscape. South Florida Ecosystem Restoration Working Group. Approved by the SCT: January 14, 2003.

Sklar, F., L. Brandt, D. DeAngelis, C. Fitz, D. Gawlik, S. Krupa, C. Madden, F. Mazzotti, C. McVoy, S. Miao, D. Rudnick, K. Rutchney, K. Tarboton, L. Vilchek, and Y. Wu. 2000. Hydrological needs - effects of hydrology on the Everglades. Pages 2-62. SFWMD. Everglades Consolidated Report, South Florida Water Management District, West Palm Beach, FL, USA.

South Florida Ecosystem Restoration Task Force (SFERTF). 1998. An Integrated Plan for South Florida Ecosystem Restoration and Sustainability: Success in the Making. The Working Group of the South Florida Ecosystem Restoration Task Force.

Stober, J., D. Scheidt, R. Jones, K. Thornton, R. Ambrose, and D. France. 1996. South Florida Ecosystem Assessment Monitoring for Adaptive Management: Implications for Ecosystem Restoration. Interim report. Environmental Protection Agency, Athens, GA, USA. EPA 904-R-96-008.
Tamiami Trail Commissioners. 1928. History of the Tamiami Trail, and a Brief Review of the Road Construction Movement in Florida. The Tamiami Trail Commissioners and the County Commissioners of Dade County, Miami, Florida. 27p.

Trustees. 1881. Articles of Agreement with Hamilton Disston for the Reclamation of the Overflowed Lands in the Valley of Lake Okeechobee and Kissimmee River. In Minutes of the Trustees, Feb. 26, 1881 Meeting. Vol. II (1904). Tallahassee, FL: Trustees of the Internal Improvement Fund.

van Dierendonck, M.C. 1992. Simulation of peat accumulation: an aid in carbon cycling research? Suo 43(4-5):203-206.

VanZee, R. 1999. Natural System Model Version 4.5 Documentation Report. Draft report, South Florida Water Management District, West Palm Beach, FL, USA. 